\title{
Unpicking antecedents of CRM adoption: a two-stage model
}

Article

Accepted Version

Jaber, F. and Simkin, L. (2017) Unpicking antecedents of CRM adoption: a two-stage model. Journal of Strategic Marketing, 25 (5-6). pp. 475-494. ISSN 1466-4488 doi:

https://doi.org/10.1080/0965254X.2016.1149212 Available at https://centaur.reading.ac.uk/53337/

It is advisable to refer to the publisher's version if you intend to cite from the work. See Guidance on citing.

To link to this article DOI: http://dx.doi.org/10.1080/0965254X.2016.1149212

Publisher: Taylor \& Francis

All outputs in CentAUR are protected by Intellectual Property Rights law, including copyright law. Copyright and IPR is retained by the creators or other copyright holders. Terms and conditions for use of this material are defined in the End User Agreement.

\section{www.reading.ac.uk/centaur}

\section{CentAUR}

Central Archive at the University of Reading

Reading's research outputs online 


\title{
Unpicking Antecedents of CRM Adoption: A Two-Stage Model
}

\begin{abstract}
Most CRM work focuses on consumer applications. This paper addresses the operational adoption issues facing the organisation deploying CRM practices. There are a plethora of challenges facing organisations when adopting CRM. Previous research is limited to either examining the CRM adoption process at an individual/employees level or an organisational level. Hence, in this paper the myriad of organisational, marketing and technical antecedents that seem to impinge upon employee perceptions and organisational implementation of CRM are structured in a two-stage model. Using a stratified sample of ten organisations across four sectors, seven hypotheses are tested on data collected from 301 practitioners. A two-stage model is analysed using structural equation modelling. Findings reveal that CRM implementation relates to employee perceptions of CRM. This paper deepens our understanding of organisational practices to adopt CRM, so as an organisation properly profits from the expected benefits of CRM.
\end{abstract}

Keywords: Customer Relationship Management; Adoption Process; Segmentation; Strategy; Knowledge Management.

\section{Author Details:}

Faten N. Jaber

Henley Business School

University of Reading, UK

Lyndon Simkin

Coventry University, UK

Corresponding author: Faten Jaber

Corresponding Author's Email: faten.jaber@ henley.ac.uk

\section{Acknowledgments}

The authors would like to thank Muneer Abbad, Ana Domingos Canhoto, andYuksel Ekinci for their very helpful comments on a previous draft of this paper. 


\section{Introduction}

Driven by the rise of social networks, mobile computing and other data warehouse technologies, as well as a greater general awareness of the importance of managing customer relationships, CRM is continuing to be a significant tool for managing interactions with customers in long-term relationships (Gummesson and Grönroos, 2012). At 13.7\% adjusted growth rate for 2013, it was the top software revenue growth market for all enterprise software markets (Gartner, 2013). And yet, early approaches viewing CRM as another technology have not generated return on investment (Forrester, 2014). In fact, given that CRM by necessity is integral to a business's system, its introduction poses a considerable challenge to businesses which are not yet ready to adapt their behaviour to the system (Forrester, 2009; Merkle Group, 2013). Indeed, many practitioners and researchers suggest that it is this inability to adapt their behaviour which leads CRM to fail in fulfilling businesses' expectations (Rigby et al., 2002; Forrester, 2014; PadillaMeléndez and Garrido-Moreno, 2014).

Prior research has either developed a broad interpretation of CRM adoption which encompasses a variety of factors affecting its adoption at an organisational level (e.g. Alshawi et al., 2011), or a narrow view of CRM focusing primarily on individual/employee behaviour (eg: $\mathrm{Wu}$ and $\mathrm{Wu}$, 2005). While there is a need for a holistic understanding of the CRM adoption process at both levels, research integrating both of them is scant. In a rare study integrating both levels of CRM adoption, Ko et al. (2008) adapted the innovation decision process component of the well-known Innovation Diffusion Theory (IDT) to conceptualise the adoption process as a two-stage model: perception and implementation. The innovation decision process, comprehensively developed by Rogers (1983, 1995), has been applied across various disciplines such as anthropology, 
sociology, education, communication, marketing, management and geography (Rogers, 1995). It is one of the primary theories applied in technology innovation (Chen et al., 2000). However, to date, it has received minimal coverage amongst CRM adoption studies.

Despite the efforts of Ko et al. (2008), their study is limited to the effects of few organisational characteristics (i.e. organisational size, CEO age, etc.) on CRM adoption, ignoring some other important organisational factors/settings. This is a major drawback since CRM adoption is a complex one, as it depends on many factors, such as strategy and customer orientation. Building on insights gleaned from different views and domains, this paper attempts to investigate the influence of a wide variety of factors on individual perception of CRM and subsequently CRM implementation across the organisation.

\section{Theoretical background and conceptual framework}

Literature analysing antecedents of innovation adoption is discussed because CRM is considered as an innovative management strategy. The IS literature provides a wide body of research which has generated different and well-known models and theories. Some of the most widely cited and employed models are the following: The Theory of Reasoned Action (Ajzen and Fishbein 1980), the Theory of Planned Behaviour (Schifter and Azjen 1985), the Technology Acceptance Model (Davis 1989; Davis et al. 1989), the Decomposed Theory of Planned Behaviour (Taylor and Todd 1995), or the Unified Theory of Acceptance and Use of Technology (Venkatesh et al., 2003). All these models consider 'behavioural intention' as the main predictor of actual behaviours or user acceptance of IT, and highlight the key role played by variables such as individuals' beliefs, attitudes, subjective norms (effect of other individuals' opinions), perceived control, perceived risk, perceived usefulness, and perceived ease of use. Based on them, 
numerous scholars have introduced other constructs with the aim of analysing the conditioning factors of user acceptance of IT (eg: Sabherwal et. al., 2006). However, it seems insufficient to simply consider employees perspective when describing organisational adoption of CRM; the adoption of CRM involves employees' acceptance, while it is also related to the diffusion of organisational strategies ( $\mathrm{Wu}$ and $\mathrm{Wu}, 2005)$. In other words, these models are only useful at an individual level to explain employees' acceptance of CRM.

On the other hand, the work of Rogers (1983) on innovation decision process provides a conceptual framework for investigating innovation adoption. Rogers (ibid) suggests that the decision to adopt a system into a company unfolds as a series of stages, flowing from knowledge of the existence of an innovation through to persuasion, decision, implementation, and confirmation. In their rare attempt to understand, in a generic sense, the adoption of a complex information system such as CRM, Ko et al. (2008) adapted the innovation decision process by Rogers (1995) and focused on two main stages of this theory: persuasion, which they referred to as perception, and implementation. The perception stage refers to cognitive beliefs underpinning an attitude towards CRM benefits. They argued that positive perception of CRM benefits would lead to decisions as to its adoption and implementation. In turn, this stage would depend on organisational deployment of specific CRM technologies/strategies.

Based on prior research and drawing on theoretical support from the adoption model of Ko et al. (2008), the conceptual model of this study is depicted in Fig.1. Two central components of CRM adoption put forward by Ko et al. (ibid) are specifically adopted here. First, employees attempt to judge the salient characteristics of the innovation and form an attitude towards the innovation. Without such information (i.e. employee perceptions), organisations may hesitate to invest in 
CRM if there is uncertainty about the benefits and costs of implementing CRM. Second, the twostage model suggests that employee perceptions may influence an organisation's decision to implement specific CRM strategies/technologies across. Hence, the intermediate capability of employee perceptions is examined here to explain the implementation of CRM throughout the organisation.

$\boldsymbol{H}_{1}$. Employee perceptions of CRM benefits mediate the effect of adoption factors on an organisation's implementation of CRM.

Building on this hypothesis, it is suggested that the actual implementation of CRM within an organisation is a result of employees' positive attitude towards CRM. This supports Day (2002) conclusion that employees' perceptions of CRM benefits must play a key role in shaping an organisation's behavioural decisions about the implementation of CRM. Such an understanding encourages organisations to commit their efforts to creating a positive attitude towards CRM among employees, by providing an environment conducive to its adoption.

While Ko's et al. (ibid) study demonstrates CRM adoption as a multi-stage process, it examines only the impact of firm characteristics, such as firm size and age, on the adoption process. Further scope exists to examine the influence of a wide variety of factors, which reflect a number of different themes and perspectives, on the adoption process. In discussing factors explaining CRM adoption, the authors base on the three main perspectives that a CRM system should cover: customer orientation, strategy and technology. These perspectives are rooted in the business and IT disciplines. 
From the business point of view, CRM is involved with marketing and management areas and reflects the development of marketing strategies that focus on customers. Researchers in the business literature focus on business strategy (Buttle, 2008), relationship marketing (Gummesson and Gönoroos, 2012) and customer-centric orientation (Baker and Hart, 2007). Accordingly, optimising customer relationship entails an inclusive understanding of profitable segments, and the alignment of business processes which will permit interaction with individual customers based on their needs (Chen and Popovich, 2003; Bailey et al., 2009). Alternatively, from a technological point of view, the IS discipline focus on CRM usage and knowledge management (KM) capabilities. Researchers from this field attempt to make efficient use of the technology to achieve value for business and are concerned with critical success factors involved in technology implementation (eg: Romano and Fjermestad, 2003).

Based on related literature from both business and IS literatures (Rigby et al., 2002; Wilson et al., 2002; Reinartz et al., 2004) it was hypothesised that six factors influence employee perceptions of CRM: customer segmentation, customer satisfaction orientation, clear direction and objectives, performance measurement, project management and KM. This is in accordance with the commonly agreed notion that CRM should be addressing three main perspectives: customer orientation, strategy and technology (Payne and Frow, 2005) and that only when all these three perspectives work in concert can a holistic understanding of the CRM adoption emerge. 
Fig.1: Conceptual Framework

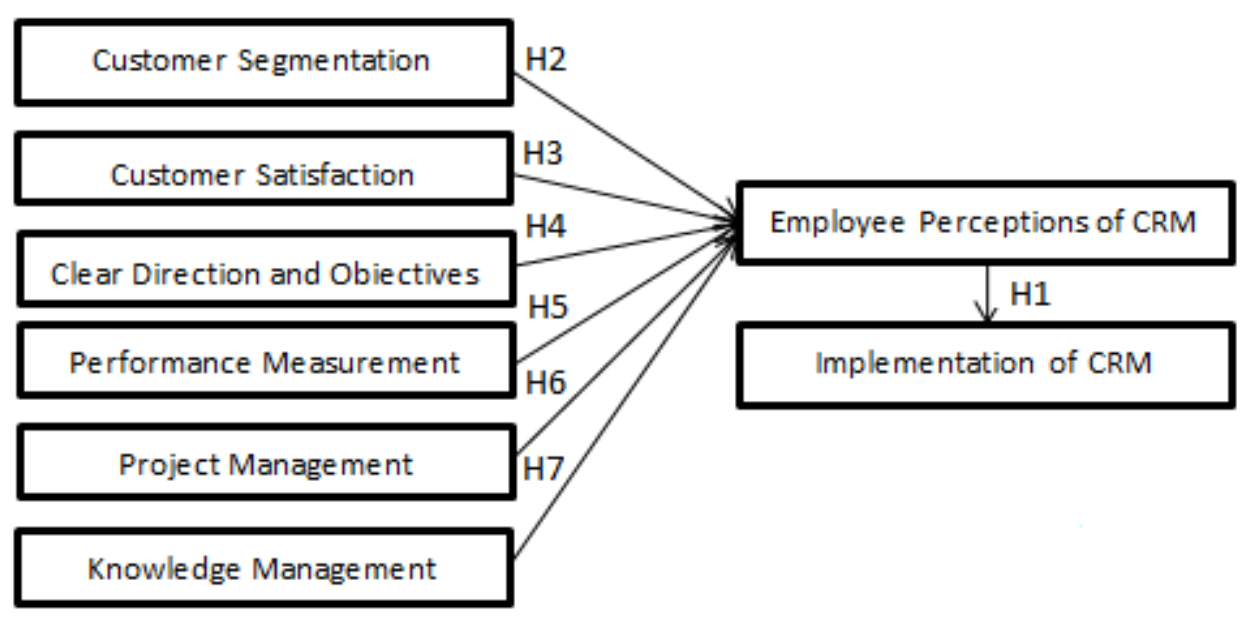

As shown in Fig.1, the perceptions of employees (dependent variable), in relation to CRM, tend to mediate the impact of adoption factors (independent variables) on the implementation of CRM strategies by an organisation (dependent variable). The following sections will discuss each variable and then describe the research methods along with the findings from this study.

\subsection{Segmentation}

Counter to the argument that CRM replaces segmentation with one-to-one customer analytics, Rigby et al. (2002) emphasise that the adoption of CRM without 'good old-fashioned segmentation' is doomed to failure. In support of this contention, Bailey et al. (2009) regard segmentation as a key component of customer insight, explaining that such segmentation plays a vital strategic and operational role in a marketing environment which includes CRM. Furthermore, reinforcing the link between segmentation and CRM allows for individualised customer treatment, increasingly imperative when businesses are seeking to broaden their understanding of customer needs, and to pursue the development of customer-centric marketing strategies (Clark and Baker, 2004). 
Recently, researchers suggest that customer segmentation is significant for redefining CRM strategies and tactics, and effective resource allocation (Meadows and Dibb, 2012; Jaber and Simkin, 2015). As they develop, businesses realise that they do not want relationships with all customers, and alternatively move to targeting more profitable customers (Van Raaij and Vernooij, 2003; Reimer et al., 2014). Hence, CRM serves as a tool to help businesses segment customers based on their potential profitability, and to build up a portfolio of relationships with customers in those segments which are, or have the potential to become profitable (Enz and Lambert, 2012). Once businesses have identified their customers' drivers and profitability, they can better develop attractive offerings to maximise the lifetime value of customers through earning their loyalty.

Meadows and Dibb (2012) propose that CRM adoption is a journey which begins with segmentation analysis and identification of profitable customers, and that customer insight provided by segmentation analysis is the first step towards customer-centric orientation. Accordingly, if organisations fulfil their responsibilities in building and updating customer databases with CRM analytical tools, they will be able effectively to segment customers and to focus on serving every customer individually, according to their unique needs and heterogeneity (Roland and Verhoef, 2005). This means that taking responsibility for segmenting customers is essential in order to meet the challenges of adopting CRM (Blattberg et al., 2009). This, which is mainly because the effective use of segmentation analysis plays a critical role in helping businesses relate more easily to CRM benefits. Thus:

\footnotetext{
$\boldsymbol{H}_{2}$. Organisation's emphasis on conducting segmentation analysis will have a positive effect on employee perceptions of CRM benefits.
} 


\subsection{Customer satisfaction orientation}

CRM is widely acknowledged as a means of retaining customers and increasing customer loyalty through superior satisfaction (Xu and Walton, 2005; Trainor et al., 2014). Most businesses actively implementing CRM have done so with a view to improving customer satisfaction, since it exploits and leverages interactive communication and genuinely involves customers with businesses to maximise their satisfaction (Chen and Popovich, 2003). The few empirical studies reviewing the link between customer satisfaction and CRM (Xu and Walton, 2005; Trainor et al., 2014) concur that major considerations for companies adopting CRM is to improve customer satisfaction level.

In theory, CRM enables businesses to understand their customers and to use this knowledge proactively to create customer value and increase customer satisfaction, especially when businesses share customer information with their suppliers and partners (Feinberg and Kadam, 2002). Thus, it could help in identifying and resolving dissatisfied customers' issues, since dissatisfied customers often do not lodge a complaint, but simply switch to another competitor (Payne, 2006). However, some researchers suggest that CRM features are not always unilaterally associated with improved customer satisfaction, and this could affect how CRM is adopted and defined within the business field (Richards and Jones, 2008). Hence, scholars need to investigate how customer satisfaction actually works in practice to support CRM adoption.

$\boldsymbol{H}_{3}$. Organisation's emphasis on customer satisfaction will have a positive effect on employee perceptions of CRM benefits. 


\subsection{Strategic direction}

Researchers suggest that CRM strategy must be incorporated within a wider context of business strategy formulation and implementation process (Reynolds, 2002). Hence, strategic planning at corporate level can help businesses to maintain a strategic fit between business strategy and CRM adoption (Ocker and Mudambi; 2003; Meadows and Dibb, 2008). Generally speaking, the position of marketing within organisations is eroded or displaced by the development of strategic planning (Day and Wensley, 1983). Such development is essential to keep the organisation engaged, focused and effective (Chen and Chen, 2004). Reynolds (2002) and Payne (2006) agree that a strong strategy is a prerequisite to focusing CRM solutions on business objectives which will yield the highest return on investment. More specifically, organisations need the strategic planning process to adapt the new customer-centric philosophy (Gurau et al., 2003).

The strategic planning process offers a coherent framework for allocating organisational resources, managing challenges, exploiting opportunities, and evaluating CRM and business performance (Bohling et al., 2006). A critical success factor of CRM implementation relies on the alignment of CRM with business strategy, organisation and process, monitoring and control, information technology, employees and culture. Therefore, organisations need to continuously locate the interrelationships among CRM activities and their business strategy and goals (Kim et al., 2003; Choudhury and Harrigan, 2014), especially since the analysis of such interrelationships can lead to deeper into the effectiveness of CRM, not just to clarify what should be done to achieve better outcomes, but also to help senior management and marketers determine their CRM strategy (Peltier et al., 2013). Accordingly, it is essential for organisations to cover CRM 
activities in their performance measurement systems, in order to assess the operation of their vision and the reliability of the strategic plan formulated to adopt CRM systems. Thus:

$H_{4}$. Incorporating clear direction and objectives that embrace CRM strategy will have a positive effect on employee perceptions of CRM benefits.

$\boldsymbol{H}_{5 .}$ Appropriate CRM performance measurement mechanisms in an organisation will have a positive effect on employee perceptions of CRM benefits.

\subsection{Project management}

The characteristics of CRM projects can make planning and control especially challenging for organisations: engagement of large teams, cross-functional perspectives, and high volatility of requirements, and complexity of company-wide programs. This is why organisations are advised to adjust plans according to contextual changes obtained during the implementation of CRM projects (Ocker and Mudambi, 2003; Payne and Frow, 2006). The ways in which this can be achieved include creating a multi-functional project team, agreeing on specific objectives for value creation, providing detailed implementation plans, providing appropriate training of users, laying out clear milestones, carrying out monitoring and motivating employees (Reynolds, 2002; Wilson et al., 2002; Payne and Frow, 2006).

CRM projects are full of surprises that considerably damage CRM credibility. So, it is hard to avoid stumbling across the facts that these projects often miss schedules, overrun budgets, or -in some cases- have to be abandoned altogether (Ebner et al., 2002). Project managers have learnt that flexibility in managing implementation plans plays a vital role in establishing the changeready environment for CRM investments (Chen and Popovich, 2003). Nevertheless, any changes 
or increase in CRM projects must be evaluated very carefully in order to avoid deviating from the intended business objectives of CRM (Payne and Frow, 2006).

Wilson et al. (2002) further explain that project management teams need to monitor and control CRM implementation, in order to ensure flexibility and adjustments to unexpected changes. The general idea that organisations with a cross-functional team assembled from different departments react more rapidly and constructively to changes than mono-functional teams (Payne, 2006). This is because a cross-functional team is able more effectively to communicate across IT and marketing departments. This results in maintaining employee team commitment to the success of a CRM project which, in turn, may lead to a more effective customised project that meets users' requirements. Such good communication management can increase the success rate of CRM projects, as it would enhance stakeholders' understanding of the project, thus obtaining their support and gaining their commitment to deliver the CRM project's results (Man et al., 2006). Thus:

$\boldsymbol{H}_{6}$. Flexibility in managing CRM projects will have a positive effect on employee perceptions of CRM benefits.

\subsection{Knowledge management}

Information technologies, such as a database, a data warehouse, data mining, online analytical processes (OLAP), a website, and an intranet/extranet aid in acquiring and interpreting customer information (eg: Hung et al., 2010). As firms begin to implement these technologies to obtain and analyse customer information, knowledge management (KM) capabilities determine how to effectively use customer information to deliver competitive advantage (Khodakarami and Chan, 2014). Since acquiring customer information - and subsequently customer knowledge - is a 
means to attaining CRM objectives, it is the case that CRM is strongly related to KM (Massey et al., 2001). Alavi and Leidner (2001, p. 8) define KM as "the knowledge-based perspective" which "postulates that the services rendered by tangible resources depend on how they are combined and applied, which is in turn a function of the firm's know-how". In this respect, KM capabilities can be referred to as 'the organisational learning' as it relates to a person or a group of people (Stein and Smith, 2009). Indeed, KM is regarded as capturing employees' knowledge about many aspects including customers, competitors and products (Rollins and Halinen, 2005).

A theoretical model of customer knowledge management (CKM) has emerged from the potential synergy between the KM and CRM fields (Khodakarami and Chan, 2014). Rollins and Halinen (2005, p.1) describe CKM as the "ongoing process of generating, disseminating and using customer knowledge within an organisation and between an organisation and its customers". Considerably, capabilities that support customer orientation and organisational learning can be seen as a platform for CRM competence. In practice, CRM adoption entails an organisation refining and realigning KM methods in order to obtain a value-added knowledge from and about customers, usefully revealing not only customer purchasing behaviour and trends but preferences and attitudes (Khodakarami and Chan, ibid). But in order to do this, an organisation implementing a CRM system needs the capability of capturing and pulling together vast amounts of information about customers. This means that CRM implementation efforts are successful when top management thinks across organisation to truly support KM dynamics. These dynamics include coordinated information gathering and sharing throughout all customer channels (Lee-Kelley and Gilbert, 2003). KM and more specifically CKM dynamics are paramount for CRM strategy, in order to equip all staff with knowledge of customer wealth so as to enhance long-term relationships with profitable customers (Bose and Sugumaran, 2003). In 
fact, the majority of CRM projects appear to fail because of improperly conducted KM, which leads to a narrow view of the customers (Romano and Fjermerstad, 2003). Thus:

\begin{abstract}
$\boldsymbol{H}_{7}$. Organisation's ability to manage customer knowledge will have a positive effect on employee perceptions of CRM benefits.
\end{abstract}

\title{
3. Methods
}

\subsection{Sample}

The services industry, characterised by a competitive environment which demands that customers receive excellent quality of service, lends itself to the study of CRM adoption. The data for this research were randomly acquired by surveying 400 members on ten companies distributed across four different industries in Jordan: banking, telecommunications, hospitality and automotive services (see Appendix I). The review of the literature shows that a number of CRM studies have investigated CRM adoption in similar industries (e.g. Chen and Li, 2006; Padilla-Meléndez and Garrido-Moreno, 2014). It is often argued that CRM adoption varies between industries (e.g. Sin et al., 2005). Thus, in investigating CRM adoption across a spread of industries, it is anticipated that the research data from this study would yield a rich and diverse picture of different kinds of potential challenge to CRM adoption, and would inform conclusions which would be generalisable across industries.

Of the 400 questionnaires distributed, 322 were returned giving a response rate of $80 \%$. After screening and reviewing the questionnaires, 21 responses were found to be invalid due to a large number of missing variables, thus were excluded from the study. This left a total number of 301 fully completed responses that were valid for final analysis giving a response rate of $75 \%$. This response rate is on a par with previous social science studies, suggesting an acceptable sample. 
Using stratified sampling, the sample consisted of a variety of firms: the banking and finance industry (32\%), telecommunications (27\%) and hotels (26\%). There were also participants from the automotive industry (12\%). In terms of business ownership, slightly fewer than half (42\%) of the organisations were owned in partnership and a considerable number (38\%) were owned by joint ventures. A large number of organisations operated internationally (64\%) and a considerable number of organisations operated regionally (35\%). More than half of the respondents (56\%) stated that their organisations had a fast response to changes in the external environment. Other organisations were classified as having a fair (39\%) or slow (3\%) response to changes.

\subsection{The research instrument}

The process of developing the research instrument in this study can be divided into four stages: i) defining variables, ii) developing scale items, iii) translating the instrument, and iv) conducting a pilot test. The instrument used three types of questions: nominal scale, seven-point likert scale and open-ended questions. After providing respondents with a general and simple definition of a CRM system, the instrument was designed to include four parts. The first one, related to CRM in the organisation, was used to collect basic information about the CRM system used by employees, and its implementation status. The second part related to the organisation's adoption of CRM. This part of the questionnaire was used to collect information regarding employee perceptions of the benefits of CRM, and the factors affecting CRM adoption (adoption stages and adoption factors measured by 9 and 26 items, respectively). The third part related to organisational characteristics including type of industry, number of employees, turnover, etc. The fourth part investigated the respondents' characteristics including gender, age, experiences, 
education level, etc. The data were collected via personally administered questionnaires distributed to practitioners of ten organisations across four sectors in Jordan.

All constructs were measured using commonly employed scales from published literature, as shown in Appendix II. CRM adoption stages (employee perceptions and CRM implementation) were measured using scale items of Ko et al. (2008). Customer segmentation was measured using elements developed by Reinartz et al. (2004) and Wu and Wu (2005). Customer satisfaction orientation was measured in accordance with Richards and Jones (2008) and Rapp et al. (2010). Strategic constructs (i.e. clear direction and objectives and performance measurement system) were measured using a modification of Meadow and Dibb's (2008). Project management construct was measured using elements of managing changes in CRM projects scale developed by Richards and Jones (2008). KM capabilities were measured using measures developed by Croteau and $\mathrm{Li}$ (2003). The results of the measure assessment and validity testing process are presented in the following section.

\section{Findings}

According to Maklan et al. (2015), most CRM implementation studies model their data using structural equation modelling (SEM). Similar to previous studies, this study employs SEM using the two-step model-building approach recommended by Anderson and Gerbing (1998): assessment of the measurement model and assessment of the structural model. The first stage of the measurement model employed confirmatory factor analysis (CFA) to confirm or reject the proposed model. Reliability and validity of items in the measurement model were examined during the CFA stage. The second stage involved using SEM on structural models to evaluate the hypothesised relationships that predict CRM adoption. 


\subsection{Reliability and validity of measures}

Based on an examination of the goodness-of-fit model variables, modification indices and largest standardised residuals, some of the original measurement items were deleted. A total of 35 items were used to measure all constructs in this study (see Appendix II). After deriving the best-fitting measurement model, a study model and related instruments were tested and assessed for validity and reliability (Hair et al., 2006). In investigating reliability, items used to measure the constructs in the conceptual model were found to be highly reliable, with all three measures of convergent validity test exceeding the suggested levels of acceptance (i.e. 0.70 for construct reliability, 0.50 for AVE, and 0.70 for construct reliability) (Anderson and Gerbing, 1998).

As indicated in Table 1, AVE estimates were greater than the corresponding interconstruct squared correlations. Therefore, the discriminant validity between factors in the measurement was able to be demonstrated. This study adopted the most commonly used goodness-of-fit measures in the marketing area, which included Chi-Square $\left(\chi^{2}\right)$, adjusted Goodness-of-fit index (AGFI), root mean square error of approximation (RMSEA), comparative fit index (CFI), and $\chi^{2}$ divided by degrees of freedom (df). As the results of the CFA demonstrated that the goodmodel-fit of the measurement model was acceptable $\left(\chi^{2}=1397, \chi^{2} / \mathrm{df}=1.70, \mathrm{AGFI}=0.86, \mathrm{CFI}=\right.$ 0.91 and RMSEA $=0.04$ ), the measurement model was incorporated into the analysis of SEM.

\subsection{Hypothesis testing}

The underlying hypotheses of this study were represented in seven paths, as outlined in Table 2. These hypotheses were directional in nature and aimed to determine the relationships among the underlying constructs in the structural model. In order to achieve rigorous test results when 
testing the directional hypotheses, a rigid level of significance within one-tailed testing was used $(\mathrm{p}<0.05)$.

The one-tailed testing suggests that path values are statistically significant when the p-value is less than 0.05 and the t-value is greater than 1.65 or smaller than -1.65 (Bryne, 2001). Accordingly, five out of the seven research hypotheses were supported/accepted; $\mathrm{H}_{1}, \mathrm{H}_{2}, \mathrm{H}_{4}, \mathrm{H}_{5}$, and $\mathrm{H}_{7}$ were found significant. As shown in Table 2, the t-values of these hypotheses (1.86 and 2.83) exceeded the recommended threshold of the one-tailed test. First, the hypothesised relationship between employee perceptions and CRM implementation within an organisation $\left(\mathrm{H}_{1}\right)$ was found to be strong and significant $(\beta=0.22, \mathrm{t}=1.86, \mathrm{p}<0.05)$. Moreover, the results suggested that four factors were important drivers of employees' perception of CRM: i) customer segmentation $(\beta=0.25, t=2.83, p<0.05)$, ii) having a clear objective of $C R M$ influences $(\beta=0.19$, $\mathrm{t}=2.10, \mathrm{p}<0.05)$, iii) strategically measuring $\mathrm{CRM}$ performance $\beta=0.19, \mathrm{t}=2.50, \mathrm{p}<0.05$ ), and iv) $\mathrm{KM}(\beta=0.20, \mathrm{t}=2.18, \mathrm{p}<0.05)$. Yet, the hypothesised positive effects of customer satisfaction orientation $\left(\mathrm{H}_{3}\right)$ and project management $\left(\mathrm{H}_{6}\right)$ on employee perceptions of CRM were rejected.

The difference in fit between the hypothesised structural model and the CFA model (i.e. the $\chi^{2}$ increased to 1450 from 1397 resulting in $\Delta \chi^{2}=53$ ) suggests that model fit can be improved by estimating other structural paths. Although, several diagnostic measures are available for researchers to indicate a potential respecification and improvement of the model and its fit indices, model respecifaction should have a theoretical and empirical support (Hair et al., 2006). Several diagnostic measures including standardised residuals, modification indices and model fit indices were therefore also examined to assess whether there were potential weaknesses in the model or some ways to improve it. These diagnostic measures were examined and modifications were made one a time as a single modification might affect other parts in the model. 
Subsequently, the standardised residuals and modification indices were analysed, resulting in potential covariance between 'clear direction' with 'CRM implementation' and 'project management' with 'CRM implementation'. Thus, potential causal links between these two factors with CRM implementation were drawn in a respecified model, as shown in Fig.2 with dashed lines. Accordingly, respecification of the model, adding two significant paths, provided a better model fit to the data $\left(\chi^{2} / \mathrm{df}=1.70, \mathrm{AGFI}=0.86, \mathrm{CFI}=0.92\right.$ and $\left.\mathrm{RMSEA}=0.04\right)$.

\section{Fig.2: Antecedants of CRM Adoption}

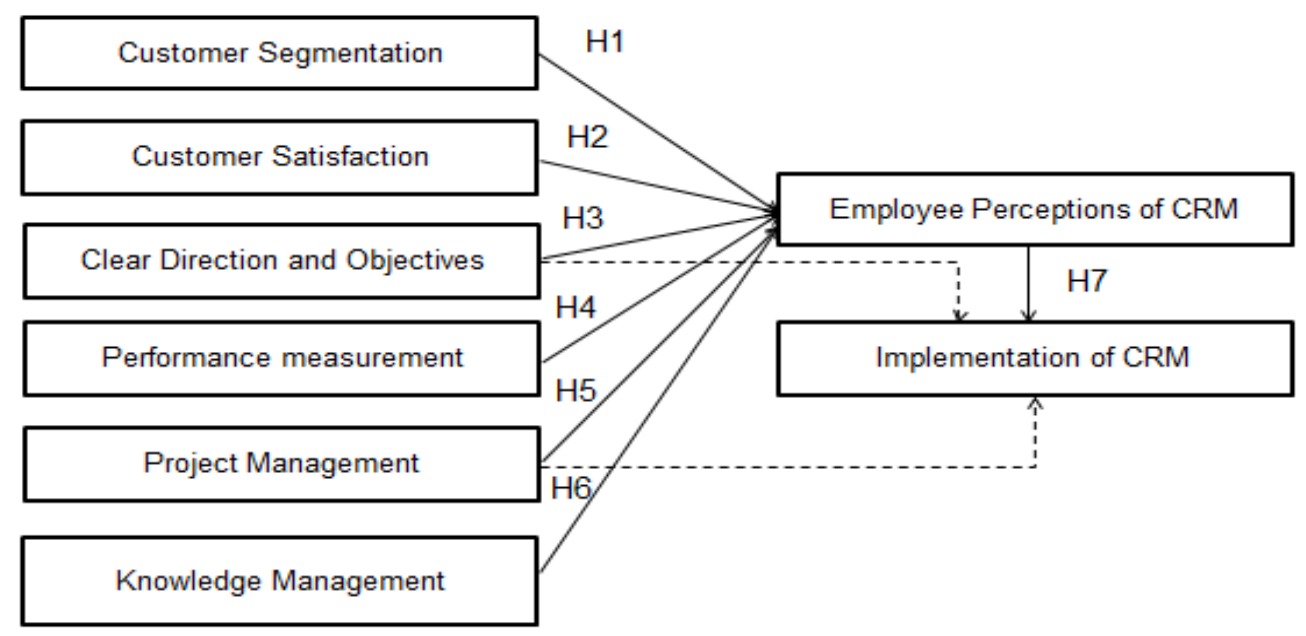

\section{Discussion}

Apparently, in this study employees' perception of CRM serves as a reasonable proxy for actual organisational implementation. The main premise is that rather than simply implementing CRM technologies, organisations should first consolidate favourable employees' perceptions towards CRM initiatives (Ko et al., 2008). A second premise is that management, while planning ahead and preparing for CRM implementation, would be advised to cultivate a culture that embraces its values (Shum et al., 2008). Based on our findings, it could be said that CRM serves to introduce a large-scale change to an organisation, and that managing this change requires the alteration or 
adaptation of employees' perceptions of CRM. Such change management often is not part of the adoption strategy for CRM, but managing this change may be achieved through four different initiatives, which are discussed below.

Segmentation has proven to be important for CRM adoption; in particular it is clear that a good segmentation analysis used by an organisation will lead to an increased understanding of CRM benefits. The reason segmentation is so important is because it highlights the importance of gaining insights as to the type and value of customers in order to plan accordingly for effective resource allocation (Meadows and Dibb, 2012). Because customer segmentation is considered as a vital precursor of CRM adoption, revisiting customer segmentation should be related to further refining of CRM strategies, processes and initiatives. Such strong links between segmentation and CRM promise to help staff relate more easily to CRM and its benefits.

The surprising findings from this study show that organisation orientation around customer satisfaction is not important for CRM. Such results suggest that CRM specifically failed to fulfil the expectations of organisations focusing on customer satisfaction. These particular organisations tended to have higher expectations from CRM. However, with CRM short-term issues arise and benefits are preserved over the longer-term (Xu and Walton, 2005). Prior studies suggest that CRM initiatives sometimes fail to be linked to increased customer satisfaction, influenced by an organisation's ability to plan and define CRM within its framework (Feinberg and Kadam, 2002; Richards and Jones, 2008). With hindsight, the noticeable failure in CRM adoption may, therefore, seem to rely on organisational failure to adopt an ideological stance to support its customer satisfaction rhetoric. 
The results confirm that an organisation should provide clear direction and objectives for CRM and a means for evaluating its performance - in order to set up desired expectations among all stakeholders. Setting a clear direction and goals for CRM, which was aligned with the overall organisational vision, will keep the organisation engaged, focused and effective (Chen and Chen, 2004). However, present discussion amongst scholars indicates that setting the right goals for CRM is not an easy process (eg: Choudhury and Harrigan, 2014). This is important, since while organisations might understand it as obvious to focus on customers, they often fail to include adequate customer data in their CRM strategies (Elmuti et al., 2009). This study suggests that different organisations need to identify the CRM objectives which are right for them, by focusing on their particular ideology for building relationships with customers, and rolling this into an overall business strategy. Expanding on the findings, the importance of building CRM strategy around customers must include how the organisation plans to acquire, develop, retain and reactivate customers. If such strategies are clear and visible to employees, there is a greater likelihood that they will then perceive and respond to CRM trends. Such clarity is often not evident to staff.

Results also suggest that having clear direction and objectives for CRM positively influences CRM implementation in terms of technology. This means that only through setting clear CRM objectives can the progress of its implementation be given impetus to accelerate. This is linked to Meadows and Dibb's (2012) findings, suggesting that the progress of CRM and its implementation is determined by the ability to plan strategically. A possible benefit from embedding clear CRM objectives in the business strategy may be the opportunity to bridge the gap between CRM plans as proposed by top management, and the progress of implementation of the CRM system. 
The results indicate that managing changes in CRM projects does not influence CRM perception amongst employees, but influences its implementation. The combination of these results suggests that project management methodologies are paying attention to the management agenda, but ignoring employee perceptions. The findings of Rigby et al. (2002), regarding the role of managing changes in CRM projects, are similar and these studies have considered two perspectives (employees and management) when evaluating and managing changes of projects, rather than a single perspective. However, there are differences observed in this study and in prior studies (e.g. Man et al., 2006) with respect to the influence of project management on employee perceptions within an organisation. These could be attributed to the reality that unless organisations have sufficient project management skills and experience to immediately respond to employee concerns, CRM risks an inauspicious start and causing antagonism or uncertainty.

The results confirm that an organisation's ability to manage customer knowledge will lead to better understanding of CRM and subsequently more innovativeness in an organisation (Rigby et al., 2002). KM capabilities serve to classify customers, predict their behaviour, influence crossselling and up-selling, and facilitate personalised marketing. From a managerial perspective, the importance of understanding the link between KM and CRM adoption is that organisations can provide the infrastructure and resources to support CRM. Hence, organisations need proactively to incorporate customer knowledge into their services, strategies and operations, for employees to value CRM capabilities (Stein et al., 2013).

\section{Conclusion}

CRM adoption is a major undertaking that requires a paradigm shift in organisational strategies, philosophies and structures. As a consequence, businesses are challenged by the difficulty of 
adopting CRM in ways which help them yield its potential benefits. Therefore, in order to develop a better understanding of the adoption process of CRM, a holistic approach, one that encompass a variety of organisational factors driving employees' perceptions and organisational deployment of CRM strategies, is undertaken in this paper.

This paper adds to the growing body of literature that investigates organisational adoption of CRM. It makes a unique contribution to extant literature by examining the influence of different organisational variables/settings on CRM adoption, which includes a series of two stages. Extant research holds the assumption that $\mathrm{CRM}$ adoption is binary (eg: $\mathrm{Wu}$ and $\mathrm{Wu}, 2005$ ); organisations either adopt CRM or they do not. Consequently, there is scarcity of studies which take into account different stages in the adoption process and do not ignore multiple adoptions of CRM by employees and their organisations. Although both stages (employees and organisational) in the adoption process may be familiar to scholars, the value of this study lies in integrating these two stages of adoption, thereby offering a more holistic picture of CRM.

This study suggests that throughout the adoption process, businesses need to develop a holistic view of CRM and its adoption by focusing on the individual level of adoption, of CRM strategies as something accepted and valued by employees, towards the organisational level of adoption, where strategy is something an organisation implements. This two-stage approach to understanding the CRM adoption process reveals that employee perceptions serve as a critical mediator between organisational efforts and actual implementation of CRM within an organisation. Moreover, factors affecting CRM adoption can have a different effect on both individual (employees) and organisational elements in the adoption stages. 
CRM introduces a new way of thinking about aligning organisational resources around building relationship with customers. This requires the use of a new set of four emerging concepts to alter employee perceptions. First, by virtue of a strategic plan, top managers need to set clear objectives and goals for CRM implementation, so that employees can have an initial idea of what CRM potentially does for the organisation. Second, as managers embrace strategic planning, CRM performance should be embedded in the performance measurement system of the organisation, so employees can perceive management commitment as sincere and resolute, which in turn will influence the implementation of CRM. Third, when moving to customercentric orientation, businesses should apply the principle of market segmentation well ahead of time, as it helps employees to appreciate CRM as a means of developing greater power of customer insight. Finally, the development of organisational capability to manage customer knowledge reflects on employee perceptions of CRM. On the other hand, if management wishes to boost the implementation of CRM strategies/technologies, two crucial initiatives should be in place: clear direction and objectives of CRM implementation and flexibility in managing changes of CRM projects.

The conceptual model and the several propositions emerging from our findings imply a rich agenda for further research. First, there is a need to assess the generalisability of the conceptual model and extend it to other businesses environments, (i.e. Europe and the USA). This is mainly because different cultures can bring different themes and perspectives to the CRM domain. Second, it is important to note that CRM adoption is expected to have overall a positive influence on business performance. Business performance is a multi-dimensional concept that may be related to several aspects including customer satisfaction, employee satisfaction, return on investment, market share and sales growth. Future research needs to investigate what 
manifests as good CRM performance. Third, although this study did not investigate the dark side practices of CRM, we view our results as linking to this area because they indicate that, CRM specifically failed to fulfil the expectations of organisations focusing on customer satisfaction. This seems sensible as these particular organisations tended to have higher expectations from CRM. However, with CRM adoption short-term issues arise and benefits are preserved over long-term (Xu and Walton, 2005). Finally, this study does not seek to incorporate the psychology discipline, with particular reference to motivation, social and workplace creativity issues. Further research should incorporate this discipline to shed light on any motivational reasons affecting CRM adoption. 


\section{References}

Ajzen, I., and Fishbein, M. (1980). Understanding Attitudes and Predicting Social Behavior. Prentice Hall, Englewood Cliffs, NJ.

Alavi, M., and Leidner, D. E. (2001). Review: Knowledge management and knowledge management systems: Conceptual foundations and research issues. MIS Quarterly 25(1), 107133.

Alshawi, S., Missi, F., and Irani, Z. (2011). Organizational, technical and data quality factors in CRM adoption - SMES perspective. Industrial Marketing Management Journal 40(3), 376-383.

Anderson, J.C., and Gerbing, D.W. (1998). Structural equation modelling in practice: a review and recommended two-step approach, Psychological Bulletin 103(3), 411-423.

Bailey, C., Baines, P.R., Wilson, H. and Clark, M. (2009). Segmentation and customer insight in contemporary services marketing practice: why grouping customers is no longer enough. Journal of Marketing Management 25(3-4), 227-252.

Baker, M., and Hart, S. (2007). Product strategy and management. $2^{\text {nd }}$ ed. Essex: Pearson Education Limited.

Bohling, T., Bowman, D., LaValle, S., Mittal, V., Narayandas, D., and Ramani, G. (2006). CRM implementation: effectiveness issues and insights. Journal of Service Research 9(2), 184-194.

Bose, R., and Sugumaran, V. (2003). Application of knowledge management technology in customer relationship management. Knowledge and Process Management 10(1), 3-17.

Buttle, F. (2008). Customer relationship management: Concepts and tools. Sydney: Elsevier.

Chen, C., Czerwinski, M., and Macredie, R. (2000). Individual differences in virtual environments - introduction and overview. Journal of the American Society for Information Science 51(6), 499-507. 
Chen, I., and Popovich, K. (2003). Understanding customer relationship management (CRM) People, process and technology. Business Process Management Journal 9(5), 672-688.

Chen, Q., and Chen, H. (2004). Exploring the success factors of e-CRM strategies in practice. Journal of Database Marketing and Customer Strategy Management 11(4), 333-343.

Chen, Y. and Li, L. (2006). Deriving information from CRM for knowledge management. A note on a commercial bank. System Research Behaviour Science 23(2), 141-146.

Choudhury, M.M., and Harrigan, P. (2014). CRM to social CRM: the integration of new technologies into customer relationship management. Journal of Strategic Marketing 22(2), 149176.

Clark, M., and Baker, S. (2004). Business Success through Service Excellence. Oxford: Elsevier Butterworth-Heinemann.

Croteau, A.M., and Li, P. (2003). Critical success factors of CRM technological initiatives. Canadian Journal of Administrative Sciences 20(1), 21-34.

Davis, F.D. (1989). Perceived usefulness, perceived ease of use, and user acceptance of information technology. MIS Quarterly 13(3), 319-340.

Davis, F.D., Bagozzi, R.P., and Warshaw, P.R. (1989). User acceptance of computer technology: a comparison of two theoretical models. Management Science 35(8), 982-1003.

Day, G.S. (2002). Winning the competition for customer relationships management: consequences for competitive advantage and performance. Working Paper, Marketing Science Institute, 02-123.

Gurau, C., Ranchhod, A., and Hackney, R. (2003). Customer-centric strategic planning: integrating CRM in online business systems. Information Technology and Management 4(2), $199-214$. 
Day, G.S., and Wensley, R. (1983). Marketing theory with a strategic orientation. Journal of Marketing 47(4), 79-89.

Ebner, M., Hu, A., Levitt, D. and McCrory, J. (2002). How to rescue CRM. The McKinsey Quarterly 48, 49-57.

Elmuti, D., Jia, H., and Gray, D. (2009). Customer relationship management strategic application and organizational effectiveness: an empirical investigation. Journal of Strategic Management 17(1), 75-96.

Feinberg, R.A., and Kadam, R. (2002). E-CRM web service attributes as determinants of customer satisfaction with retail web sites. International Journal of Service Industry Management 13(5), 432-451. s

Forrester Research (2014). Map the way to your CRM business outcomes. Available at: https://www.forrester.com/Map+The+Way+To+Your+CRM+Business+Outcomes/fulltext/-/E-

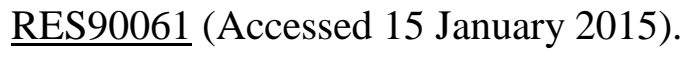

Gartner (2013). Market share analysis: customer relationship management software, worldwide, 2013. Available at: https://www.gartner.com/doc/2711518?srcId=1-2819006590andpcp=itg (Accessed 15 January 2015).

Gummesson, E., and Grönroos, C. (2012). The emergence of the new service marketing: Nordic School perspectives. Journal of Service Management 23(4), 479-497.

Hair, J., Black, W.C., Babin, B., Anderson, R.E., and Tatham, R.L. (2006). Multivariate Data Analysis. $6^{\text {th }}$ ed. Englewood Cliffs: Prentice Hall.

Hung, Y., Hung, W., Tsai, C., and Jiang, S. (2010). Critical factors of hospital adoption on CRM system: Organizational and information system perspectives. Decision Support Systems 48(4), 592-603. 
Jaber, F., Simkin, L. (2015) 'Making Customer Relationship Management Effective in Organisations'. Paper to be represented at Academy of Marketing Conference, Limerick, Republic of Ireland, 7-9 July.

Khodakarami, F., and Chan, Y.E. (2014). Exploring the role of customer relationship management (CRM) systems in customer knowledge creation. Information and Management 51(1) 27-42.

Ko, E., Kim, S.H., Kim, M., and Woo, J. (2008). Organizational characteristics and the CRM adoption process. Journal of Business Research 61(1), 65-74.

Lee-Kelley, L., Gilbert, D., and Mannicom, R. (2003). How e-CRM can enhance customer loyalty. Marketing Intelligence and Planning 21(4), 239-248.

Maklan, M., Peppard, J., and Klaus, P. (2015). Show me the money: improving our understanding of how organizations generate return from technology-led marketing change. European Journal of Marketing 49(3/4), 561-595.

Man, C.W., Kong, W.Y.W., Yui, W.H.E., and Tam, P.F.J. (2006). A study of CRM implementation in financial industry. International Conference on e-Learning, e-Business, Enterprise Information Systems, e-Government, and Outsourcing, 237-244.

Massey, A., Montoya, M. and Holcom, K. (2001). Re-engineering the customer Frelationship: leveraging knowledge assets at IBM. Decision Support Systems 32(2), 155-170.

Meadows, M., and Dibb, S. (2008). Progress in customer relationship management adoption: a cross-sector study of financial services, professional services and the government/public sector. Proceedings of the British Academy of Management Conference. Harrogate.

Meadows, M., and Dibb, S. (2012). Progress in customer relationship management adoption: a cross-sector study. Journal of Strategic Marketing 20(4), 323-344. 
Merkle Group (2013). Customer-centric transformation: five keys to leading successful change. Available at: $\quad$ www.merkleinc.com/sites/default/files/whitepapers/Customer-CentricTransformation_WEB_4\%2030\%2014.pdf (accessed 10 October 2014).

Ocker, J., and Mudambi, S. (2003). Assessing the readiness of firms for CRM: a literature review and research model. Proceedings of the 36th Hawaii International Conference on System Sciences (HICSS '03).

Padilla-Meléndez, A., and Garrido-Moreno, A. (2014). Customer relationship management in hotels: examining critical success factors. Current Issues in Tourism 17(5), 387-396.

Payne A., and Frow P. (2005). A strategic framework for customer relationship management. Journal of Marketing 69(4), 167-76.

Payne, A. (2006). Handbook of CRM: Achieving excellence in customer management. Amsterdam: Butterworth-Heinemann.

Rapp, A., Trainor, K.J., and Agnihotri, R. (2010). Performance implications of customer-linking capabilities: Examining the complementary role of customer orientation and CRM technology. Journal of Business Research 63(11), 1229-1236.

Reimer, K., Rutz, O.J., and Pauwels, K. (2014). How online consumer segments differ in longterm marketing effectiveness. Journal of Interactive Marketing 28(4), 271-284.

Reinartz, W.J., Krafft, M., and Hoyer, W.D. (2004). The customer relationship management process: its measurement and impact on performance. Journal of Marketing Research 41(3), 293-305.

Reynolds, J. (2002). A Practical Guide to CRM building more profitable customer relationships. New York: CMP Books.

Richards, K.A., and Jones, E. (2008). Customer relationship management: finding value drivers. Industrial Marketing Management 37(2), 120-130. 
Rigby, D.K., Reichheld F.F., and Schefter, P. (2002). Avoid the four perils of CRM. Harvard Business Review 80(2), 101-109.

Rogers, E.M. (1983). Diffusion of Innovations. $3^{\text {rd }}$ ed. New York: Free Press.

Rogers, E.M. (1995). Diffusion of innovations. $4^{\text {th }}$ ed. New York: Free Press.

Roland, R., and Verhoef, P.C. (2005). Optimizing the marketing interventions mix in intermediate-term CRM. Marketing Science 24(3), 477-489.

Rollins, M., and Halinen, A. (2005).Customer Knowledge Management Competence: Towards a Theoretical Framework. Proceedings of the 38th Hawaii International Conference on System Sciences. Big Island, HI (pp. 1-10).

Romano, N.C., and Fjermestad, J. (2003). Electronic customer relationship management: a research agenda. Information Technology and Management 4(2-3), 233-258.

Schifter, D.E., Azjen, I. (1985). Intention, perceived control, and weight loss: An application of the theory of planned behavior. J. Personality and Soc. Psych. 49(3), 843-851.

Shum, P., Bove, L. and Auh, S. (2008). Employee's affective commitment to change. The key to successful CRM implementation. European Journal of Marketing 42(11-12), 1346-1371.

Sin, L.Y.M., Tse, A.C.B., and Yim, F.H.K. (2005). CRM: conceptualization and scale development. European Journal of Marketing 39(11/12), 1264-1290.

Stein, A., Smith, M. (2009). CRM systems and organizational learning: An exploration of the relationship between CRM effectiveness and the customer information orientation of the firm in industrial markets. Industrial Marketing Management 38(2), 198-206

Stein, A.D., Smith, M.F., and Lancioni, R.A. (2013). The development and diffusion of customer relationship management $(\mathrm{CRM})$ intelligence in business-to-business environments. Industrial Marketing Management 42(6), 855-861. 
Taylor, S., and Todd, P. (1995). Decomposition and crossover effects in the theory of planned behavior: a study of consumer adoption intentions. International Journal of Research in Marketing 12, 137-55.

Trainor, K.J., Andzulis, J., Rapp, A., and Agnihotri, R. (2014). Social media technology usage and customer relationship performance: A capabilities-based examination of social CRM. Journal of Business Research 67(6), 1201-1208.

Trainor, K.J., Rapp, A., Beitelspacher, L., and Schillewaert, N. (2011). Integrating information technology and marketing: an examination of the drivers and outcomes of e-Marketing capability. Industrial Marketing Management 40(1), 162-174.

Venkatesh, V., Morris, M.G., Davis, G.B., and Davis, F.D. (2003). User Acceptance of Information Technology: Toward a Unified View. Management Information Systems Quarterly $27(3), 426-478$.

Wilson, H., Daniel, E. and McDonald, M. (2002). Factors for success in customer relationship management (CRM) systems. Journal of Marketing Management 18(1/2), 193-219.

Wu, K.L., and Wu, K.W. (2005). A hybrid technology acceptance approach for exploring eCRM adoption in organizations. Behaviour and Information Technology 24(4), 303-316.

$\mathrm{Xu}, \mathrm{M}$., and Walton, J. (2005). Gaining customer knowledge through analytical CRM. Industrial Management and Data Systems 105(7), 955-71. 


\section{Appendix I. Organisations' Characteristics}

\begin{tabular}{|c|c|c|}
\hline Variable & No of respondents & Percent (\%) \\
\hline \multicolumn{3}{|c|}{ Industry } \\
\hline Banking and Finance & 99 & 32.8 \\
\hline Telecommunication & 83 & 27.4 \\
\hline Hotel & 81 & 26.9 \\
\hline Automotive & 38 & 12.6 \\
\hline \multicolumn{3}{|c|}{ Number of employees } \\
\hline 25 or less & 7 & 2.3 \\
\hline $26-50$ & 8 & 2.7 \\
\hline $51-100$ & 12 & 4.0 \\
\hline $101-155$ & 3 & 1.0 \\
\hline $151-200$ & 13 & 4.3 \\
\hline More than 201 & 258 & 85.7 \\
\hline \multicolumn{3}{|c|}{ Turnover } \\
\hline Less than $25 \mathrm{~m}$ & 86 & 28.6 \\
\hline $26 m-50 m$ & 52 & 17.3 \\
\hline $51 \mathrm{~m}-100 \mathrm{~m}$ & 33 & 11.0 \\
\hline $101 \mathrm{~m}-155 \mathrm{~m}$ & 6 & 2.0 \\
\hline $151 \mathrm{~m}-200 \mathrm{~m}$ & 19 & 6.3 \\
\hline More than $201 \mathrm{~m}$ & 86 & 28.6 \\
\hline \multicolumn{3}{|c|}{ Ownership type } \\
\hline Sole proprietorship & 20 & 6.6 \\
\hline Partnership & 128 & 42.5 \\
\hline Joint venture & 117 & 38.9 \\
\hline Subsidiary & 10 & 3.3 \\
\hline Associate company & 2 & .7 \\
\hline Corporation & 6 & 2.0 \\
\hline Other & 18 & 6.0 \\
\hline \multicolumn{3}{|c|}{ Operation of the organisation } \\
\hline Regional & 108 & 35.9 \\
\hline International & 193 & 64.1 \\
\hline \multicolumn{3}{|c|}{ Speed of response to change } \\
\hline Slow & 11 & 3.7 \\
\hline Fair & 120 & 39.9 \\
\hline Fast & 170 & 56.5 \\
\hline
\end{tabular}




\section{Appendix II. Factors and Scale Items}

\begin{tabular}{|c|c|c|}
\hline Factor & Variables & \\
\hline \multirow[t]{2}{*}{ Segmentation } & Using customer information to segment markets. & \multirow{2}{*}{$\begin{array}{l}\text { Reinartz et al., 2004; } \mathrm{Wu} \text { and } \\
\mathrm{Wu}, 2005\end{array}$} \\
\hline & Segmenting customers based on their lifetime. & \\
\hline \multirow{3}{*}{$\begin{array}{l}\text { Customer } \\
\text { satisfaction }\end{array}$} & Organisation strategy is driven by customer satisfaction. & \multirow{3}{*}{$\begin{array}{l}\text { Richards and Jones, 2008; Rapp } \\
\text { et al., } 2010\end{array}$} \\
\hline & Frequently and systematically measuring customer satisfaction. & \\
\hline & Responding quickly to negative customer satisfaction wherever it may occur. & \\
\hline \multirow{3}{*}{$\begin{array}{l}\text { Clear direction } \\
\text { and objectives }\end{array}$} & Clear business goals related to customer acquisition, development, and retention. & \multirow{3}{*}{$\begin{array}{l}\text { Meadows and Dibb, 2008; Chang } \\
\text { et al., 2010; Rapp et al., } 2010\end{array}$} \\
\hline & The majority of the employees are aware of the organisation's vision. & \\
\hline & Approaching customers as an important part of the organisational vision. & \\
\hline \multirow{4}{*}{$\begin{array}{l}\text { Performance } \\
\text { management } \\
\text { system }\end{array}$} & There is a set of clear priorities for CRM projects. & \multirow{4}{*}{$\begin{array}{l}\text { Salomann et al., 2005; Raman et } \\
\text { al., 2006; Meadows and Dibb, } \\
\text { 2008; Richards and Jones, } 2008\end{array}$} \\
\hline & These CRM projects are consistent with the organisation's vision and statements. & \\
\hline & Regularly measuring the effectiveness and the success of CRM activities. & \\
\hline & Segmenting customers based on their lifetime. & \\
\hline \multirow{3}{*}{$\begin{array}{l}\text { Project } \\
\text { management }\end{array}$} & Giving users' ideas due attention in the CRM planning and implementation process. & \multirow{3}{*}{$\begin{array}{l}\text { Wilson et al., 2002; Richards and } \\
\text { Jones, 2008; }\end{array}$} \\
\hline & Meeting changes in CRM requirements by users or due to business environment change. & \\
\hline & The IT function has the ability to adjust CRM project plans on an ad hoc basis. & \\
\hline \multirow{3}{*}{$\begin{array}{l}\text { Knowledge } \\
\text { management }\end{array}$} & Providing fast customer response because of integrated customer knowledge across several functional areas. & \multirow{3}{*}{$\begin{array}{l}\text { Croteau and Li 2003; Hung et al., } \\
2010\end{array}$} \\
\hline & Providing fast decision-making due to customer knowledge availability. & \\
\hline & Providing authentic customer information for quick and accurate interaction. & \\
\hline \multirow{4}{*}{$\begin{array}{l}\text { Employee } \\
\text { perceptions of } \\
\text { CRM }\end{array}$} & Increase customer satisfaction. & \multirow[t]{4}{*}{ Ko et al., 2008} \\
\hline & Increase customer retention rate. & \\
\hline & Increase revenue and profitability. & \\
\hline & Enhance customer relationships. & \\
\hline \multirow{5}{*}{$\begin{array}{l}\text { Implementation } \\
\text { of CRM }\end{array}$} & Offering customer loyalty programs & \multirow[t]{5}{*}{ Ko et al., 2008} \\
\hline & Managing customer loyalty & \\
\hline & Developing member-only site in your organisation's website & \\
\hline & Categorizing/segmenting customers based on spending (lifetime value) & \\
\hline & Providing products and services in one place & \\
\hline
\end{tabular}


Table 1

Measure Validity Tests and Construct Intercorrelations

\begin{tabular}{lcccccccc}
\hline & $\mathbf{1 .}$ & $\mathbf{2 .}$ & $\mathbf{3 .}$ & $\mathbf{4 .}$ & $\mathbf{5 .}$ & $\mathbf{6 .}$ & $\mathbf{7 .}$ & $\mathbf{8 .}$ \\
\hline 1. Segmentation & 1 & .07 & .04 & .04 & .08 & .03 & .02 & .03 \\
2. Customer satisfaction & .26 & 1 & .11 & .06 & .08 & .11 & .14 & .07 \\
3. Clear direction and objectives & .19 & .33 & 1 & .20 & .09 & .12 & .18 & .13 \\
4. Performance measurement system & .20 & .24 & .45 & 1 & .06 & .08 & .16 & .08 \\
5. Project management & .28 & .29 & .30 & .25 & 1 & .05 & .05 & .08 \\
6. Knowledge management & .16 & .33 & .34 & .28 & .23 & 1 & .13 & .05 \\
7. Perception & .13 & .37 & .43 & .40 & .22 & .36 & 1 & .03 \\
8. Implementation & .16 & .26 & .36 & .28 & .28 & .22 & .16 & 1 \\
\hline Average variance extracted & .63 & .55 & .68 & .53 & .51 & .62 & .55 & .55 \\
Composite reliability & .75 & .77 & .86 & .77 & .76 & .83 & .83 & .77 \\
Mean & 5.5 & 5.8 & 5.6 & 5.3 & 5.5 & 5.5 & 5.8 & 5.3 \\
Standard deviation & 1.28 & 1.10 & 1.14 & 1.23 & 1.28 & 1.15 & 1.10 & 1.39 \\
\hline
\end{tabular}

${ }^{a}$ Values below the diagonal (numbers in italics) are correlations: values above the diagonal are squared correlations.

Table 2

Hypothesis Testing

\begin{tabular}{|c|c|c|c|}
\hline $\begin{array}{l}\text { Hypothesis } \\
\text { Number }\end{array}$ & Relationship & $\begin{array}{c}\text { Path } \\
\text { Estimate }\end{array}$ & t-value \\
\hline H1 & perception $\longrightarrow$ implementation & .22 & $1.86 *$ \\
\hline $\mathrm{H} 2$ & customer segmentation $\longrightarrow$ perception & .25 & $2.83 *$ \\
\hline $\mathrm{H} 3$ & customer satisfaction $\longrightarrow$ perception & -.03 & -.51 \\
\hline $\mathrm{H} 4$ & clear direction and objectives $\longrightarrow$ perception & .19 & $2.10 *$ \\
\hline H5 & performance measurement $\longrightarrow$ perception & .19 & $2.50 *$ \\
\hline H6 & project management $\longrightarrow$ perception & -.08 & -.77 \\
\hline H7 & knowledge management $\longrightarrow$ perception & .20 & $2.18 *$ \\
\hline & clear direction and objectives $\longrightarrow$ implementation & .36 & 3.10* \\
\hline & project management $\longrightarrow$ implementation & .24 & $2.35 *$ \\
\hline \multicolumn{4}{|c|}{ Model Fit Statistics } \\
\hline \multicolumn{2}{|c|}{$X^{2}$} & \multicolumn{2}{|r|}{1397} \\
\hline \multicolumn{2}{|l|}{$x^{2} / D f$} & \multicolumn{2}{|r|}{1.70} \\
\hline \multicolumn{2}{|l|}{$A G F I$} & \multicolumn{2}{|r|}{.86} \\
\hline \multicolumn{2}{|l|}{$C F I$} & \multicolumn{2}{|r|}{.92} \\
\hline \multicolumn{2}{|l|}{ RMSEA } & \multicolumn{2}{|r|}{.048} \\
\hline \multicolumn{4}{|c|}{ Variance explained $\left(R^{2}\right)$} \\
\hline \multicolumn{2}{|l|}{ Perception } & \multicolumn{2}{|r|}{.60} \\
\hline \multicolumn{2}{|c|}{ Implementation } & & .48 \\
\hline
\end{tabular}

*Significant at $\mathbf{p}<0.05$ 